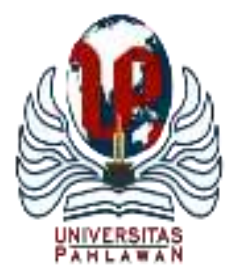

\title{
JURNALBASICEDU
}

Volume 6 Nomor 1 Tahun 2022 Halaman 709 - 716

Research \& Learningin Elementary Education

https://jbasic.org/index.php/basicedu

\section{Efektivitas Model Pembelajaran Project Based Learning Terhadap Kemampuan Literasi Numerasi Dan Literasi Digital Peserta Didik Madrasah Ibtidaiyah}

\author{
Nadia Risya Faridah ${ }^{1 凶}$, Eka Nur Afifah², Siti Lailiyah ${ }^{3}$ \\ UIN Sunan Ampel Surabaya, Indonesia ${ }^{1,2,3}$ \\ E-mail: nadiarisya37@gmail.com ${ }^{1}$, ekanurafifah1@gmail.com ${ }^{2}$, lailiyah@uinsby.ac.id ${ }^{3}$
}

\begin{abstract}
Abstrak
Penelitian ini bertujuan untuk menganalisis tingkat efektivitas model pembelajaran PjBL (Project Based Learning) dalam meningkatkan kemampuan literasi numerasi dan literasi digital pada peserta didik madrasah ibtidaiyah. Pendekatan yang digunakan adalah kuantitatif dengan metode eksperimen dan desain penelitian yang digunakan adalah control group pretest-posttest design. Dengan menggunakan teknik random sampling, diperoleh sampel untuk kelas eksperimen dan kontrol. Pada kelas eksperimen diberikan perlakuan dengan model pembelajaran PjBL (Project Based Learning) dan pembelajaran konvensional dengan metode ceramah pada kelas kontrol. Data kemampuan literasi numerasi dan literasi digital tersebut diperoleh menggunakan tes tulis berupa angket yang didukung oleh pemberian soal pilihan ganda dan benar-salah pada peserta didik. Hasil dari penelitian yaitu penggunaaan model pembelajaran PjBL (project-based learning) efektif digunakan dalam meningkatkan kemampuan literasi numerasi dan literasi digital pada peserta didik kelas V MI AlFithrah Surabaya. Dengan perolehan nilai signifikansi sebesar 0,107 $<0,05$ menunjukkan hasil bahwa terdapat pengaruh yang signifikan dari variabel independent (X) terhadap semua variabel dependen (Y1 dan Y2). Hal ini terlihat pada pengaruh yang terjadi di kelas eksperimen yang diberikan perlakuan model pembelajaran PjBL (project-based learning) lebih unggul dibandingkan dengan kelas kontrol yang menggunakan model pembelajaran konvensional.
\end{abstract}

Kata Kunci: Model Pembelajaran PjBL (Project-Based Learning), Literasi Numerasi, Literasi Digital.

\begin{abstract}
This study aims to analyze the level of effectiveness of the PjBL (Project Based Learning) learning model in improving numeracy literacy and digital literacy skills for students of Madrasah Ibtidaiyah. The approach used is quantitative with experimental methods and the research design used is the control group pretest-posttest design. By using random sampling technique, samples were obtained for the experimental and control classes. The experimental class was given treatment with the PjBL (Project Based Learning) learning model and conventional learning with the lecture method in the control class. The numeracy literacy and digital literacy ability data were obtained using a written test in the form of a questionnaire supported by the provision of multiple choice and true-false questions to students. The result of the research is that the use of the PjBL (project-based learning) learning model is effectively used in improving numeracy literacy and digital literacy skills in fifth grade students at MI Al-Fithrah Surabaya. With the acquisition of a significance value of $0.107<0.05$, it shows the results that there is a significant effect of the independent variable $(X)$ on all dependent variables (Y1 and Y2). This can be seen in the effect that occurs in the experimental class that is given the treatment of the PjBL learning model (project-based learning) which is superior to the control class that uses the conventional learning model. Keywords: PjBL (Project-Based Learning) Learning Model, Numerical Literacy, Digital Literacy.
\end{abstract}

Copyright (c) 2022 Nadia Risya Faridah, Eka Nur Afifah, Siti Lailiyah

$\triangle$ Corresponding author :

Email : nadiarisya37@gmail.com

DOI : $: \overline{h t t p s: / / d o i . o r g / 10.31004 / b a s i c e d u . v 6 i 1.2030 ~}$

ISSN 2580-3735 (Media Cetak)

ISSN 2580-1147 (Media Online)

Jurnal Basicedu Vol 6 No 1 Tahun 2022 p-ISSN 2580-3735 e-ISSN 2580-1147 
DOI: https://doi.org/10.31004/basicedu.v6i1.2030

\section{PENDAHULUAN}

Pada abad ke-21, pendidikan menjadi unsur penting dalam menjamin peserta didik untuk memiliki keterampilan belajar dan berinovasi, serta keterampilan dalam menggunakan teknologi dan media informasi (Muliastrini, 2020). Menyiapkan peserta didik yang berkualitas dan mampu bersaing secara global merupakan tantangan bagi Lembaga Pendidikan dalam beradaptasi dengan perkembangan zaman yang terjadi pada abad ke-21. Peserta didik tidak hanya dituntut untuk menguasai kemampuan bahasa, ilmu pengetahuan, matematika dan seni saja melainkan diharapkan dapat bekerja dan bertahan dengan keterampilan untuk hidup (life skill) (Murti, 2014). Hal ini sejalan dengan pernyataan Partnership for $21^{\text {st }}$ Century Learning bahwa kecakapan di abad-21 dapat dikembangkan melalui beberapa kecakapan yakni kecakapan berpikir kritis dan pemecahan masalah, kecakapan berkomunikasi, kecakapan kreativitas dan inovasi (creativity and innovation), serta kecakapan kolaborasi (Ardilah, 2020). Salah satu prasyarat dalam mewujudkan kecakapan pada abad ke-21 adalah kemampuan literasi pada peserta didik.

Literasi yang secara sederhana dapat diartikan sebagai kemampuan membaca dan menulis (Dewi, 2019). Seiring dengan perkembangan zaman, saat ini literasi tidak hanya diartikan sebagai kemampuan menulis dan membaca saja melainkan memiliki makna yang cukup meluas (multi literacies) (Suwandi, 2018). Seperti yang dicantumkan dalam Buku Saku Gerakan Literasi Sekolah bahwa literasi bermakna kemampuan dalam mengakses, memahami dan menggunakan informasi secara cerdas (Nugraha \& Octavianah, 2020). Terdapat berbagai macam kemampuan literasi yang perlu dikuasai oleh peserta didik, beberapa diantaranya adalah literasi numerasi dan literasi digital.

Literasi numerasi merupakan pengetahuan dan kecakapan untuk menggunakan berbagai macam angka dan simbol yang berkaitan dengan matematika dasar guna memecahkan masalah praktis dalam kehidupan sehari-hari lalu menganalisis informasi yang ditampilkan dalam berbagai bentuk serta menginterpretasi hasil analisis untuk memprediksi dan mengambil keputusan (Kemdikbud, 2017). Sejalan dengan pernyataan tersebut, Ekowati et al., (2019) mengartikan literasi numerasi sebagai kemampuan sesorang dalam menganalisis dan memahami suatu pernyataan yang dikemas melalui aktivitas dalam memanipulasi simbol atau bahasa yang ditemukan dalam kehidupan sehari-hari, serta mengungkapkan pernyataan tersebut melalui tulisan maupun tulisan. Kemampuan literasi numerasi menjadi garda terdepan dalam memberikan perlindungan dini terhadap tingkat pengangguran, penghasilan yang rendah dan kesehatan yang buruk. Seperti yang dipaparkan Ekowati dan Suwandayani (2017) dalam bukunya bahwa keterampilan numerasi sangat dibutuhkan pada berbagai aspek kehidupan, baik di rumah, pekerjaan maupun di masyarakat. Seperti halnya dalam kehidupan bermasyarakat dan bernegara, dimana informasi mengenai ekonomi dan politik tidak bisa dihindari sehingga seseorang perlu memahami dan menginterpretasikan informasi yang disajikan dalam bentuk numerik atau grafik. Kemampuan literasi numerasi ditunjukkan dengan adanya kenyamanan terhadap bilangan dan mampu menggunakan keterampilan matematika secara praktis dalam memenuhi tuntutan kehidupan. Kemampuan ini juga merujuk pada apresiasi dan pemahaman informasi yang dinyatakan secara matematis, misalnya grafik, bagan, dan tabel (Mahmud et al., 2019).

Berdampingan dengan era digital pada abad ke-21, kemampuan literasi numerasi akan semakin menarik jika diimbangi dengan kemampuan literasi digital agar dapat memperkokoh kecakapan peserta didik dalam bersaing secara global. Generasi yang tumbuh dengan akses yang tidak terbatas dalam teknologi digital akan memiliki pola berpikir yang berbeda dengan generasi sebelumnya. Secara terminologi, UNESCO menyatakan bahwa lterasi digital merupakan kecakapan (life skill) yang tidak hanya melibatkan kemampuan menggunakan perangkat teknologi, informasi, dan komunikasi, tetapi juga kemampuan bersosialisasi, kemampuan dalam pembeljajaran, dan memiliki sikap, berpikir kritis, kreatif, serta inspiratif sebagai kompetensi digital (Jian Xi Teng, Program Officer, UNESCO ICT, 2018). Oleh karena itu, literasi digital akan membentuk tatanan 

Lailiyah

DOI: https://doi.org/10.31004/basicedu.v6i1.2030

peserta didik dengan pola pikir dan pandangan yang kritis dan kreatif dan jika peserta didik belum terbentuk kemampuan literasi digital menjadi sangat berisiko terhadap persaingan dalam memperoleh pekerjaan dan interaksi sosial (Simarmata et al., 2021).

Beberapa organisasi dan lembaga pendidikan bersinergi untuk mengupayakan kegiatan pembelajaran yang menunjang peningkatan kemampuan literasi numerasi dan literasi digital peserta didik. Adanya tuntutan capaian pembelajaran yang semakin kompleks menjadikan penggunaan media, strategi pembelajaran serta model pembelajaran memiliki peran penting dalam hal tersebut. Seperti terlihat dalam penelitian yang telah dilakukan oleh Winarni et al., (2021) bahwa upaya yang dilakukan untuk mendukung kemampuan literasi numerasi dan digital peserta didik dengan menggunakan video pembelajaran menuai hasil bahwa penggunaan media video pembelajaran matematika dapat meningkatkan kemampuan literasi numerasi. Hal ini terlihat bahwa hasil tes literasi numerasi peserta didik di kelas eksperimen dan kelas kontrol memiliki perbedaan secara signifikan dengan kondisi secara deskriptif hasil tes di kelas eksperimen lebih tinggi. Upaya lain juga terlihat dari penelitian yang dilakukan oleh Widiastuti \& Kurniasih (2021) mendapatkan hasil bahwa bahwa model problem-based learning berbantuan software cabri 3D V2 berpengaruh terhadap literasi numerasi peserta didik pada kelas 8 Sekolah Menengah Pertama Negeri 5 Tambun Selatan. Merujuk pada penelitian yang telah dilakukan dapat ditarik kesimpulan bahwa penggunaan media maupun model pembelajaran yang sesuai akan berpengaruh terhadap tingkat kemampuan literasi peserta didik, khususnya pada literasi numerasi dan literasi digital. Adapun yang menjadi penelitian ini berbeda dengan yang telah dilakukann adalah penggunaan model pembelajaran dalam peningkatan literasi ganda yakni literasi numerasi dan literasi digital serta pemilihan subjek penelitian yang diteliti.

Berdasarkan hasil observasi, pada salah satu lembaga pendidikan di Surabaya yakni MI Al-Fithrah Surabaya diketahui rendahnya kemampuan dalam konsep bilangan dan keterampilan operasi hitung di dalam kehidupan sehari-hari. Tak hanya itu, kemampuan dalam mendapatkan informasi, dan mengelola informasi secara digital juga masih perlu perbaikan. Dengan upaya pembelajaran dengan pendekatan teacher center berbentuk ceramah menjadikan kemampuan literasi numerasi serta literasi digital belum bisa berkembang dan terbentuk dengan baik dalam diri peserta didik. Oleh karena itu, peneliti tertarik menggunakan model pembelajaran PjBL (Project Based Learning) sebagai upaya mendukung serta membudayakan kemampuan literasi numerasi dan literasi digital pada peserta didik.

Model pembelajaran PjBL (Project Based Learning) bertumpu pada konsep pembelajaran konstruktivis sehingga model ini mampu mendukung peserta didik membangun pengetahuannya atas pengalamannya sendiri. Pada model pembelajaran PjBL (Project Based Learning) ini dirancang agar peserta didik mampu menyelesaikan sebuah masalah melalui aktivitas proyek, dengan adanya kerja proyek ini peserta didik akan mendapat pengalaman nyata tentang perencanaan suatu proyek (Surya et al., 2018). Adapun kelebihan menggunakan model pembelajaran PjBL (Project Based Learning) yaitu dapat meningkatkan motivasi peserta didik dalam menyusun proyek, meningkatkan kemampuan pemecahan masalah, meningkatkan kolaborasi dan kekompakan, serta meningkatkan keterampilan mengelola sumber (Niswara et al., 2019). Dengan mengacu paparan di atas, peneliti tertarik untuk mengulik lebih dalam terkait tingkat efektivitas yang terjadi dalam penggunaaan model pembelajaran PjBL (Project Based Learning) terhadap kemampuan literasi numerasi dan literasi digital peserta didik di MI Al-Fithrah Surabaya, sehingga penelitian ini bertujuan untuk melihat efektivitas model pembelajaran PjBL (Project Based Learning) yang digunakan dalam proses pembelajaran terhadap kemampuan literasi numerasi dan literasi digital peserta didik. 
Dan Literasi Digital Peserta Didik Madrasah Ibtidaiyah - Nadia Risya Faridah, Eka Nur Afifah, Siti Lailiyah

DOI: https://doi.org/10.31004/basicedu.v6i1.2030

\section{METODE PENELITIAN}

Penelitian ini menggunakan pendekatan kuantitatif dengan metode eksperimen dan desain penelitian yang digunakan adalah control group pretest-posttest design. Populasi yang digunakan dalam penelitian adalah peserta didik kelas V di MI Al-Fitrah Surabaya yang telah diketahui bahwa kemampuan dalam memahami konsep bilangan dan keterampilan operasi hitung di dalam kehidupan sehari-hari belum sesuai dengan indikator pada literasi numerasi. Selain itu, kemampuan dalam mendapatkan dan mengelola informasi secara digital juga belum sepenuhnya berjalan dengan baik.

Teknik pengambilan sampel menggunakan random sampling dimana setiap peserta didik diberikan kesempatan yang sama untuk dapat menjadi sampel penelitian (Sumargo, 2020). Pada populasi yang dipilih terdapat 5 rombel kelas dengan jumlah sebanyak 130 peserta didik, yang nantinya akan dipilih secara acak untuk memenuhi 1 kelas kontrol dan 1 kelas eksperimen dengan jumlah masing-masing kelas sebanyak 22 peserta didik. Sebagai kelas kontrol akan memperoleh pembelajaran dengan pendekatan teacher center berbentuk ceramah dan sebagai kelas eksperimen akan diberi perlakuan berupa pembelajaran dengan model pembelajaran PjBL (Project Based Learning).

Instrumen penelitian yang digunakan adalah instrumen wawancara, instrumen observasi, instrumen tes dan angket kemampuan literasi numerasi dan literasi digital. Instrumen wawancara digunakan untuk menggali informasi dari guru dan peserta didik terkait karakteristik peserta didik, kondisi pada proses pembelajaran sebelum dan setelah menggunakan model pembelajaran PjBL (Project Based Learning). Instrumen observasi digunakan sebagai panduan pengamatan kondisi peserta didik dan kesesuaian langkahlangkah dalam pelaksanaan pembelajaran model pembelajaran PjBL (Project Based Learning). Instrumen tes berisi 9 soal dengan bentuk soal berupa 3 soal pilihan ganda dan 6 soal benar-salah sebagai alat yang digunakan untuk mengukur kemampuan literasi numerasi dan literasi digital peserta didik. Dan angket kemampuan literasi numerasi dan literasi digital disajikan dengan menggunakan skala likert dengan 5 alternatif jawaban yakni Sangat Setuju (5), Setuju (4), Ragu-ragu (3), Tidak Setuju (2), Sangat Tidak Setuju (1) yang digunakan untuk memperkuat instrument tes dalam mengukur peningkatan kemampuan literasi numerasi dan literasi digital peserta didik setelah dilakukannya proses pembelajaran pada kelas kontrol dan kelas eksperimen.

Teknik pengumpulan data yang digunakan dalam penelitian adalah wawancara, observasi dan tes. Sebelum dilakukan penelitian, peneliti melakukan validasi isi instrument yang digunakan dalam penelitian kepada 1 dosen ahli dan 2 guru kelas untuk menganalisis ketepatan isi terhadap variabel yang akan diteliti agar tujuan penelitian yang diharapkan dapat tercapai. Selanjutnya, peneliti melakukan observasi dan mengikuti proses pembelajaran yang dilaksanakan oleh guru pada kelas kontrol dan eksperimen. Setelah pembelajaran telah selesai, instrument tes dan angket penelitian diberikan melalui google form yang diisi oleh peserta didik secara individu.

Analisis data pada tingkat efektivitas model pembelajaran PjBL (project-based learning) terhadap kemampuan literasi numerasi dan literasi digital menggunakan uji Manova (Multivariate Analysis of Variance). Langkah dalam pengujian data tersebut yakni 1) uji pendahuluan guna mengetahui validitas dan reliabilitas instrument, 2) pengumpulan data, 3) analisis data awal mencakup uji normalitas dan uji homogenitas menggunakan aplikasi SPSS versi 25 untuk menguji apakah data dua kelas tersebut berdistribusi normal dan homogen yang betujuan untuk mengetahui sebaran data serta untuk memilih persamaan yang akan digunakan saat melakukan uji hipotesis (Suwandari et al., 2018), 4) Uji perbedaan rata-rata dan uji Manova (Multivariate Analysis of Variance) untuk melihat efektifitas penggunaan model pembelajaran PjBL terhadap kemampuan literasi numerasi dan kemampuan literasi digital peserta didik. 
Dan Literasi Digital Peserta Didik Madrasah Ibtidaiyah - Nadia Risya Faridah, Eka Nur Afifah, Siti Lailiyah

DOI: https://doi.org/10.31004/basicedu.v6i1.2030

\section{HASIL DAN PEMBAHASAN}

\section{Efektivitas Model Pembelajaran PjBL (Project Based Learning) Terhadap Kemampuan Literasi} Numerasi dan Literasi Digital Peserta Didik

Hasil analisis data yang diperoleh terkait efektivitas model pembelajaran PjBL (project-based learning) terhadap peningkatan kemampuan literasi numerasi dan literasi digital peserta didik yang melibatkan 22 peserta didik di MI Al-Fitrah Surabaya dianalisis menggunakan teknik analisis Manova (Multivariate Analysis of Variance) untuk mengetahui pengaruh variabel independen $(\mathrm{X})$ terhadap variabel dependen pertama (Y1) dan variabel dependen kedua (Y2).

Hasil perhitungan uji validitas angket peningkatan literasi numerasi didapatkan bahwa dari 8 item pernyataan yang dinyatakan valid sebanyak 7 item dan 1 item dinyatakan tidak valid, sehingga angket peningkatan literasi numerasi yang digunakan dalam penelitian ini sebanyak 7 item pernyataan, dan hasil uji reliabilitas dinyatakan reliabel dengan nilai alpha 1,11 . Sedangkan untuk hasil perhitungan uji validitas angket literasi digital sebanyak 7 item dinyatakan valid dengan hasil uji reliabilitas dinyatakan reliabel dengan nilai alpha 1,10. Tabel 1 menunjukkan hasil pengujian angket peningkatan literasi numerasi dan literasi digital peserta didik.

Tabel. 1 Hasil Uji Validitas Angket Peningkatan Literasi Numerasi dan Literasi Digital Peserta didik

\begin{tabular}{ccccc}
\hline \multirow{2}{*}{$\mathbf{r}^{\text {tabel }}$} & \multicolumn{2}{c}{ Literasi Numerasi } & \multicolumn{2}{c}{ Literasi Digital } \\
\cline { 2 - 5 } & $\mathbf{r}^{\text {hitung }}$ & Simpulan & $\mathbf{r}^{\text {hitung }}$ & Simpulan \\
\hline 0,423 & 0,508 & Valid & 0,588 & Valid \\
\hline 0,423 & 0,561 & Valid & 0,403 & Valid \\
\hline 0,423 & 0,520 & Valid & 0,616 & Valid \\
\hline 0,423 & 0,505 & Valid & 0,570 & Valid \\
\hline 0,423 & 0,473 & Valid & 0,573 & Valid \\
\hline 0,423 & 0,738 & Valid & 0,638 & Valid \\
\hline 0,423 & 0,259 & Invalid & 0,429 & Valid \\
\hline 0,423 & 0,426 & Valid & \\
\hline
\end{tabular}

Instrumen penelitian ini telah divalidasi oleh 1 orang berprofesi sebagai dosen ahli pendidikan dan 2 orang berprofesi sebagai guru kelas. Sehingga instrumen dapat digunakan sesuai dengan tujuan penelitian. Secara umum, hasil dari penggunaan angket penelitian yang diuji menggunakan uji Manova (Multivariate Analysis of Variance) diuraikan sebagaimana berikut.

Selanjutnya dilakukan analisis statistik deskriptif untuk melihat efektivitas dari model pembelajaran PjBL terhadap peningkatan kemampuan literasi numerasi dan literasi digital. Berdasarkan tabel deskripsi pada Tabel 2 terlihat bahwa rata-rata kemampuan literasi numerasi dan literasi digital kelas kontrol lebih rendah dari rata-rata kemampuan literasi numerasi dan literasi digital kelas eksperimen. Dengan kualifikasi rata-rata nilai angket kelas kontrol masuk ke dalam kategori rendah dibandingkan kualifikasi rata-rata nilai angket kelas eksperimen.

Tabel 2. Deskripsi Statistik Kemampuan Literasi Numerasi dan Literasi Digital

\begin{tabular}{clccc}
\hline & Kelas & Mean & Std. Deviation & N \\
\hline Literasi & Eksperimen & 29.59 & 2.840 & 22 \\
Numerasi & Kontrol & 27.82 & 2.648 & 22 \\
& Total & 28.70 & 2.858 & 44 \\
Literasi & Eksperimen & 28.41 & 3.261 & 22 \\
Digital & Kontrol & 27.00 & 3.055 & 22 \\
& Total & 27.70 & 3.203 & 44 \\
\hline
\end{tabular}


Dan Literasi Digital Peserta Didik Madrasah Ibtidaiyah - Nadia Risya Faridah, Eka Nur Afifah, Siti Lailiyah

DOI: https://doi.org/10.31004/basicedu.v6i1.2030

Selanjutnya melakukan uji normalitas dan uji homogenitas untuk melihat apakah data yang diperoleh sudah berdistribusi normal dan bersifat homogen. Pelaksanaan hal tersebut sebagai prasyarat sebelum dilaksanakan pengujian Manova (Multivariate Analysis of Variance). Hasil yang diperoleh pada uji normalitas dapat dilihat pada Tabel 3 dan uji homogenitas pada Tabel 4.

Tabel 3. Uji Normalitas One Sample Kolmogorov Smirnov

\begin{tabular}{lcccccc}
\hline & Model & \multicolumn{2}{c}{ Kolmogorov-Smirnov } & \multicolumn{2}{c}{ Shapiro-Wilk } \\
\cline { 3 - 7 } & PjBL & Statistic & df & Sig. & Statistic & df \\
\hline Literasi Numerasi & 1 & .170 & 22 & .098 & .939 & 22 \\
\hline Literasi Digital & 1 & .141 & 22 & $.200^{*}$ & .932 & 22 \\
\hline
\end{tabular}

Tabel 4. Uji Homogenitas

\begin{tabular}{lcccc}
\hline & Levene Statistic & df1 & df2 & Sig. \\
\hline Literasi Numerasi & .000 & 1 & 42 & .986 \\
\hline Literasi Digital & .121 & 1 & 42 & .730 \\
\hline
\end{tabular}

Berdasarkan hasil pada Tabel 3 terkait uji normalitas yang menggunakan one sample kolmogorovsmirnov, Nilai signifikansi yang diperoleh pada variabel literasi numerasi adalah 0,098>0,05 dan nilai signifikansi variabel literasi digital sebesar 0,200 >0,05 sehingga data tersebut dikatakan berdistribusi normal. Sedangkan untuk hasil uji homogenitas yang terlihat pada Tabel. 4, menunjukkan signifikansi > 0,05 sehingga data tersebut dinyatakan homogen.

Setelah dilakukan uji normalitas dan uji homogenitas dikatakan normal dan homogen, lalu dilanjutkan dengan melakukan uji Manova (Multivariate Analysis of Variance). untuk melihat efektivitas penggunaan model model pembelajaran PjBL (project-based learning) terhadap peningkatan kemampuan literasi numerasi dan literasi digital peserta didik.

Tabel 5. Hasil Uji Multivariate

\begin{tabular}{llccccc}
\hline & Effect & Value & F & Hypothesis df & Error df & Sig. \\
\hline \multirow{3}{*}{ Intercept } & Pillai's Trace & .993 & $2731.546^{\mathrm{b}}$ & 2.000 & 41.000 & .000 \\
\cline { 2 - 7 } & Wilks' Lambda & .007 & $2731.546^{\mathrm{b}}$ & 2.000 & 41.000 & .000 \\
\cline { 2 - 7 } & Hotelling's Trace & 133.246 & $2731.546^{\mathrm{b}}$ & 2.000 & 41.000 & .000 \\
\cline { 2 - 7 } & Roy's Largest Root & 133.246 & $2731.546^{\mathrm{b}}$ & 2.000 & 41.000 & .000 \\
\hline \multirow{3}{*}{ Kelas } & Pillai's Trace & .103 & $2.362^{\mathrm{b}}$ & 2.000 & 41.000 & .107 \\
\cline { 2 - 7 } & Wilks' Lambda & .897 & $2.362^{\mathrm{b}}$ & 2.000 & 41.000 & .107 \\
\cline { 2 - 7 } & Hotelling's Trace & .115 & $2.362^{\mathrm{b}}$ & 2.000 & 41.000 & .107 \\
\cline { 2 - 7 } & Roy's Largest Root & .115 & $2.362^{\mathrm{b}}$ & 2.000 & 41.000 & .107 \\
\hline
\end{tabular}

Berdasarkan tabel analisis multivariat diatas, diperoleh nilai signifikansi sebesar $0,107<0,05$. Sehingga hasil analisis statistik multivariat tersebut menunjukkan bahwa terdapat pengaruh yang signifikan dari variabel independent $(\mathrm{X})$ terhadap semua variabel dependent (Y1 dan Y2). Sehingga dapat diartikan bahwa penggunaan model $\mathrm{PjBL}$ dapat meningkatkan kemampuan literasi numerasi dan kemampuan literasi digital peserta didik.

Hasil uji Manova (Multivariate Analysis of Variance) secara keseluruhan yang telah diuraikan menunjukkan bahwa model pembelajaran PjBL (project-based learning) terbukti efektif dalam meningkatkan kemampuan literasi digital dan literasi numerasi peserta didik. Hal ini terlihat pada pengaruh yang terjadi di kelas eksperimen yang diberikan perlakuan model pembelajaran PjBL (project-based learning) lebih unggul dibandingkan dengan kelas kontrol yang menggunakan model pembelajaran konvensional. Adanya 
penggunaan model pembelajaran PjBL (project- based learning) mempengaruhi peserta didik dapat mengomunikasikan hasil konstruk terkait pengalaman yang ia miliki dengan materi literasi numerasi dan literasi digital, menjadi lebih aktif memberikan gagasan yang ia miliki, mampu merepresentasikan situasi matematika ke dalam bentuk grafik, tabel, diagram maupun persamaan, daya berpikir kreatif dan berpikir kritis meningkat. Tak hanya itu, peserta didik dapat menyaring informasi yang diperoleh dari internet tanpa perlu diingatkan serta dapat menjaga etika dalam menggunakan internet dengan baik.

Hasil penelitian ini sejalan dengan penelitian yang dilakukan oleh Khotimah (2020) yang berhasil menuai hasil bahwa penggunaan model pembelajaran $\mathrm{PjBL}$ (project-based learning) mempengaruhi tingkat kreativitas berpikir peserta didik, karena dalam proses pembelajaran mereka dilatih untuk meningkatkan kreatifitas berpikirnya, yang dimulai dari memberikan gagasan, dan juga pada proses pengerjaan LKS secara berkelompok memiliki permasalahan yang sama sehingga siswa dapat saling mengoreksi ketika presentasi berlangsung. Selain itu, penelitian yang dilakukan oleh Wicaksana dan Ridlo (2017) juga mendukung hasil pada penelitian ini bahwa penggunaan model pembelajaran PjBL (project-based learning) dapat meningkatkan karakter rasa ingin tahu epistemik dan memiliki pengaruh kepada kemampuan literasi matematika. Kemampuan yang memperoleh pengaruh tersebut diantaranya adalah communicating, mathematizing, representation, reasoning, using symbolic formal and technical operation dan using mathematics tools. Dalam penelitian yang dilakukan oleh Abidin et al., (2020) juga mengungkapkan bahwa pembelajaran berbasis proyek literasi merupakan model pembelajaran yang baik dan efektif dalam memfasilitasi siswa dalam meningkatkan kemampuan penalaran matematis.

\section{KESIMPULAN}

Berdasarkan hasil analisis dan pembahasan dapat disimpulkan bahwa penggunakaan model pembelajaran PjBL (project-based learning) efektif digunakan dalam meningkatkan kemampuan literasi numerasi dan literasi digital pada peserta didik kelas V MI Al-Fithrah Surabaya. Dengan perolehan nilai signifikansi sebesar 0,107 $<0,05$ menunjukkan hasil bahwa terdapat pengaruh yang signifikan dari variabel independent $(\mathrm{X})$ terhadap semua variabel dependen (Y1 dan $\mathrm{Y} 2$ ). Hal ini terlihat pada pengaruh yang terjadi di kelas eksperimen yang diberikan perlakuan model pembelajaran PjBL (project-based learning) lebih unggul dibandingkan dengan kelas kontrol yang menggunakan model pembelajaran konvensional. Sehingga melalui penelitian ini, indikator yang diharapkan dalam pelaksanaan literasi numerasi dan literasi digital dapat dicapai oleh peserta didik. Dalam penggunaan model pembelajaran PjBL (project-based learning), peserta didik juga menyatakan persetujuannya bahwa proses dalam model pembelajaran PjBL (project-based learning) dapat membantu mereka dalam meningkatkan kemampuan literasi numerasi dan literasi digital.

\section{DAFTAR PUSTAKA}

Abidin, Z., Utomo, A. C., Pratiwi, V., \& Farokhah, L. (2020). Pembelajaran Project Based Learning - Literasi Dalam Meningkatkan Kemampuan Penalaran Matematis Siswa Di Sekolah Dasar. Educational Journal Of Bhayangkara, 1(1), 30-36. Https://Doi.Org/10.31599/Edukarya.V1i1.106

Ardilah, N. (2020). Efektivitas Media Pembelajaran My Classroom Creation Wall Dalam Meningkatkan Kemampuan Literasi Sains Peserta Didik. Jurnal Pena Karakter (Jurnal Pendidikan Anak Dan ..., 03(01).

Dewi, P. Y. A. (2019). Gerakan Membaca Di Awal Pelajaran Guna Membangun Budaya Literasi Di Sekolah Dasar. Journal Of Chemical Information And Modeling, 53(9), 77-85. Http://Jayapanguspress.Penerbit.Org/Index.Php/Pn/Article/View/249 
Dan Literasi Digital Peserta Didik Madrasah Ibtidaiyah - Nadia Risya Faridah, Eka Nur Afifah, Siti Lailiyah

DOI: https://doi.org/10.31004/basicedu.v6i1.2030

Ekowati, D. W., Astuti, Y. P., Utami, I. W. P., Mukhlishina, I., \& Suwandayani, B. I. (2019). Literasi Numerasi Di Sd Muhammadiyah. Else (Elementary School Education Journal) : Jurnal Pendidikan Dan Pembelajaran Sekolah Dasar, 3(1), 93. Https://Doi.Org/10.30651/Else.V3i1.2541

Khotimah, H. (2020). Pengaruh Model Pembelajaran Project Based Learning Terhadap Kreatifitas Berpikir Dan Literasi Sains Siswa Sman 1 Abstrak. 2(1), 13-26.

Mahmud, M. R., Pratiwi, I. M., Islam, U., Sunan, N., Djati, G., Islam, U., Sunan, N., \& Djati, G. (2019). Literasi Numerasi Siswa Dalam Pemecahan Masalah Tidak Terstruktur. 4(1), 69-88.

Muliastrini, N. K. E. (2020). New Literacy Sebagai Upaya Peningkatan Mutu Pendidikan Sekolah Dasar Di Abad 21. Jurnal Pendidikan Dasar Indonesia, 4(1), 115-125.

Murti, E. K. (2014). Pendidikan Abad 21. Pendidikan Abad 21, $3,5$. Http://Yana.Staf.Upi.Edu/2015/10/11/Pendidikan-Abad-21/

Niswara, R., Fita, M., \& Untari, A. (2019). Pengaruh Model Project Based Learning Terhadap High Order Thinking Skill. Mimbar Pgsd Undiksha, 7(2), 86.

Nugraha, D., \& Octavianah, D. (2020). Diskursus Literasi Abad 21 Di Indonesia. Jurnal Pendidikan Edutama, 7(1), 107. Https://Doi.Org/10.30734/Jpe.V7i1.789

Sumargo, Bagus (2020), Teknik Sampling, Jakarta: Uns Press

Simarmata, Janner, Dkk (2021), Literasi Digital, Medan: Yayasan Kita Menulis

Surya, A. P., Relmasira, S. C., \& Hardini, A. T. A. (2018). Penerapan Model Pembelajaran Project Based Learning (Pjbl) Untuk Meningkatkan Hasil Belajar Dan Kreatifitas Siswa Kelas Iii Sd Negeri Sidorejo Lor 01 Salatiga. Jurnal Pesona Dasar, 6(1), 41-54. Https://Doi.Org/10.24815/Pear.V6i1.10703

Suwandari, P. K., Taufik, M., \& Rahayu, S. (2018). Pengaruh Model Pembelajaran Inkuiri Terbimbing Terhadap Penguasaan Konsep Dan Keterampilan Proses Sains Fisika Peserta Didik Kelas Xi Man 2 Mataram Tahun Pelajaran 2017/2018. Jurnal Pendidikan Fisika Dan Teknologi, 4(1), 82. Https://Doi.Org/10.29303/Jpft.V4i1.541

Suwandi, S. (2018). Pembelajaran Bahasa Indonesia Yang Mencerdaskan Dan Tanggung Jawab Menghasilkan Generasi Literat. Fon: Jurnal Pendidikan Bahasa Dan Sastra Indonesia, 13(2), 1-17. Https://Doi.Org/10.25134/Fjpbsi.V13i2.1562

Teng, Jian Xi, Digital Literacy And Beyond, Unesco Ict In Education (2018). Diakses Pada Tanggal 8 Desember 2021 Pada Laman Https://Www.Unescap.Org/

Wicaksana, Y., \& Ridlo, S. (2017). Analisis Kemampuan Literasi Matematika Dan Karakter Rasa Ingin Tahu Siswa Pada Pembelajaran Berbasis Proyek Berbantuan Schoology. 6(2), 167-174.

Widiastuti, E. R., \& Kurniasih, M. D. (2021). Pengaruh Model Problem Based Learning Berbantuan Software Cabri 3d V2 Terhadap Kemampuan Literasi Numerasi Siswa. Jurnal Cendekia: Jurnal Pendidikan Matematika, 5(2), 1687-1699. Https://Doi.Org/10.31004/Cendekia.V5i2.690

Winarni, S., Kumalasari, A., Marlina, M., \& Rohati, R. (2021). Efektivitas Video Pembelajaran Matematika Untuk Mendukung Kemampuan Literasi Numerasi Dan Digital Siswa. Aksioma: Jurnal Program Studi Pendidikan Matematika, 10(2), 574. Https://Doi.Org/10.24127/Ajpm.V10i2.3345 